Área Abierta. Revista de comunicación

audiovisual y publicitaria

ISSN: 2530-7592 / ISSNe: 1578-8393

http://dx.doi.org/10.5209/ARAB.61464

\title{
La praxis fílmica en los estudios académicos
}

Presentación: José Ángel Lázaro López

El dossier para el que el presente texto pretende servir como introducción es al mismo tiempo un punto de llegada y de partida. De llegada, en tanto que naturalmente constituye el resultado de tres trabajos académicos que, planteados y desarrollados en común por sus tres autores bajo un proyecto de reflexión y actuación compartido, ha servido para la constitución de un grupo de trabajo y un foro de debate en el seno de la comunidad universitaria que considerábamos necesario $\mathrm{y}$, ahora, felizmente constituido.

Estos tres textos abordan la temática planteada, la necesidad de repensar el saber académico sobre la creación cinematográfica, desde una triple perspectiva, impulsada por una ambición de diversidad y, a la vez, complementariedad. Luis Alonso se ocupa del enfoque epistemológico; José María Galindo ofrece una propuesta metodológica; y José Ângel Lázaro acomete la perspectiva pedagógica. Como nexo teórico común, los tres trabajos esbozan, en diferente grado, propuestas alrededor de la "praxis fílmica" como necesario concepto a desarrollar en el que el saber y el hacer del cine se reencuentran y se miran de manera consustancial.

Todas las propuestas planteadas tienen como punto de contacto el manifiesto "Burch's cluB: sobre la praxis fílmica, bajo o contra el cine", redactado por Alonso y suscrito por Galindo y Lázaro, con el que los tres autores pretenden centrar, sin por ello cerrar, el debate, y señalar los espacios de crisis, así como comenzar a liberar la conversación de sus recurrentes cul-de-sac, y esbozar líneas directrices sobre sus propuestas básicas para replantear la perspectiva de estudio.

A partir de estos trabajos, este dossier supone también, como decíamos, un claro punto de partida para este grupo de trabajo y el foro de debate académico propuesto, pero también, y de manera muy decidida, el inicio de un debate más allá del ámbito académico y docente. Respecto al aspecto futurible del grupo de discusión académico, desde ahora queremos abrir el debate y extender la conversación a todas y todos los compañeros interesados e implicados en la reflexión teórica y la docencia sobre la praxis fílmica, en toda la amplitud y con todo el alcance que sea posible. Los textos aquí publicados pretenden, en la medida de la fuerza que su unión y enfoque múltiple les provea, servir de primera posta para un recorrido de actuaciones en el campo académico que no ceje, gracias a este impulso recién adquirido, de perseguir el horizonte de reformulación de un campo crucial en los estudios fílmicos que necesita, a nuestro juicio, de una nueva perspectiva y una nueva conciencia sobre su propia condición.

En cuanto a la propuesta de expandir la conversación fuera del campo académico, la primera intervención propuesta es, precisamente, un conversatorio dirigido a hacer 
aflorar las cuestiones críticas de la cuestión, abierto en el tiempo y los espacios de debate, y dirigido primeramente a los y las directores y directoras de cine españoles de todas las generaciones, estilos y tipos de producción, que conviven en el actual escenario del que aún llamamos "mundo del cine".

Los contenidos clave derivados de la primera serie de cineastas entrevistados y puestos en diálogo con las ideas y propuestas será, con mucha probabilidad, la continuación natural, en cuanto a su reflejo editorial, de las actuaciones en marcha, así como la primera materia prima en la elaboración de materiales, tanto escritos como audiovisuales, con los que seguir trabajando en esta línea de investigación.

Noviembre de 2018 